\title{
(IN)VALIDADE DAS CONVENÇÕES PROCESSUAIS ATÍPICAS E VULNERABILIDADE: UMA ANÁLISE À LUZ DO AUTORREGRAMENTO DA VONTADE ${ }^{1}$
}

(IN) VALIDITY OF ATYPICAL PROCEDURAL CONVENTIONS AND VULNERABILITY: AN ANALYSIS IN THE LIGHT OF AUTONOMY OF THE WILL

Edson Freitas de Oliveira Doutorando em Direito pela Unimar (Universidade de Marília), Mestre em direito pela Instituição Toledo de Ensino de Bauru/SP., professor e coordenador de pós-graduação do Centro Universitário "Antônio Eufrásio de Toledo" de Presidente Prudente. Presidente Prudente, São Paulo, Brasil. E-mail: edson@freitasaragos.adv.br

Pedro Augusto de Souza Brambilla Graduado em Direito pelo Centro Universitário “Antônio Eufrásio de Toledo" de Presidente Prudente, Pós-Graduado e professor na mesma instituição. Mestre em Ciências Jurídicas pelo Centro Universitário de Maringá (UNICESUMAR). Coordenador do Grupo de Iniciação Científica "Novo Processo Civil Brasileiro: Garantias Fundamentais e Inclusão Social” do Programa de Iniciação Científica do Centro Universitário "Antônio Eufrásio de Toledo" de Presidente Prudente, São Paulo, Brasil. E-mail: pedro@zsassociados.com.

Laura Junqueira

Discente do Curso de Direito do Centro Universitário "Antônio Eufrásio de Toledo" de Presidente Prudente. Pesquisadora bolsista no Grupo de Iniciação Científica "Novo

\footnotetext{
${ }^{1}$ Artigo recebido em 11/08/2020 e aprovado em 29/10/2020.
} 
Processo Civil Brasileiro: Garantias Fundamentais e Inclusão Social" do Programa de Iniciação Científica do Centro Universitário "Antônio Eufrásio de Toledo" de Presidente Prudente (Edital PROAC n 02 de 04 de fevereiro de 2020). Pesquisadora no Grupo Transformações nas Estruturas Fundamentais do Processo (membro da ProcNet - Rede Internacional de Pesquisa em Justiça Civil e Processo Contemporâneo). Presidente Prudente, São Paulo, Brasil. Email: laura.junqueira@outlook.com.br.

RESUMO: O autorregramento da vontade incide não apenas no Direito Privado, mas também no Direito Público, como é o caso do Direito Processual Civil. O Código de Processo Civil de 2015 materializou tal princípio em diversos dispositivos, evidenciando o protagonismo assumido pelas partes no modelo processual contemporâneo. Nesse sentido, o artigo 190 possibilita que as partes realizem negócios processuais atípicos. Entretanto, seu parágrafo único impõe limitações à liberdade dos convenentes quando um deles for vulnerável. Relevante, portanto, analisar a liberdade, igualdade e vulnerabilidade aplicadas no processo civil, delimitando-se como se realizará o controle de validade das convenções processuais pelo magistrado.

PALAVRAS-CHAVE: Autorregramento da vontade. Convenções Processuais Atípicas. Igualdade. Vulnerabilidade. Controle de Validade.

\begin{abstract}
The autonomy of the will affects not only Private Law, but also Public Law, such as Civil Procedural Law. The 2015 Code of Civil Procedure materialized this principle in several devices, showing the protagonism assumed by the parties in the contemporary procedural model. In this sense, article 190 of the new procedural law allows parties to perform atypical procedural conventions. However, its sole paragraph imposes limitations on the liberty of the parties when one of them is vulnerable. It is important, therefore, to analyze the liberty, equality and vulnerability applied in civil proceedings, delimiting how the validity control of procedural conventions by the magistrate should be carried out.
\end{abstract}


KEY WORDS: Autonomy of the Will. Atypical Procedural Conventions. Equality. Vulnerability. Validity Control.

\section{INTRODUÇÃO}

O Código de Processo Civil de 2015, apesar de não ser mais tão "novo", como muitos ainda insistem em dizer, continua sendo objeto de diversas pesquisas e debates, seja pela gama de novidades implementadas, seja pela ausência de posicionamentos jurisprudenciais sobre diversas questões relevantes e polêmicas na doutrina.

O tema a que se propôs este trabalho - a negociação sobre matéria processual -, sem dúvidas, coloca-se em posição de destaque dentre as inúmeras polêmicas na nova legislação processual. Isso porque, apesar de não ser uma novidade legislativa, tendo em vista que o Código de Processo Civil de 1973 já admitia a negociação processual, o artigo 190 do atual código processual ampliou a possibilidade de negociação. Tal cláusula geral de negociação processual, sem dúvidas, é um dos exemplos da relevância dada ao autorregramento da vontade no Código de Processo Civil de 2015.

Portanto, num primeiro momento, relevante o estudo dos reflexos do princípio do autorregramento da vontade no processo e na legislação processual. Para tanto, mister se fez traçar as fases metodológicas do processo civil, como forma de compreender a passagem de um processo privatista para o que alguns entendem ser um "hiperpublicismo", até a construção do modelo processual contemporâneo. Merece destaque, nesse sentido, a onda de constitucionalização do Direito que, em sua vertente processual, recebeu a denominação de neoprocessualismo ou formalismo-valorativo.

Em seguida, destacou-se o caráter participativo do processo, evidenciado pelo Código de Processo Civil de 2015, que, em diversos dispositivos, privilegia a vontade das partes, as quais retomam o protagonismo no palco processual. Deu-se, pois, destaque especial ao artigo 190 da lei processual, que possibilita a negociação atípica, ampliando os poderes das partes sobre o procedimento.

Ocorre que, em contrapartida ao caráter essencialmente negocial estampado no caput do artigo 190, seu parágrafo único elenca as hipóteses em que o juiz, de ofício ou a 
requerimento, controlará a validade das convenções processuais, devendo, portanto, deixar de aplicar o que foi convencionado.

Interessou, para fins da presente pesquisa, a hipótese de invalidação do negócio firmado por parte vulnerável. Nesse sentido, inicialmente, foram feitas algumas ponderações sobre o princípio da igualdade, o qual serviu como base para posterior análise da vulnerabilidade processual. Após, num estudo da vulnerabilidade processual propriamente dita, coube analisar seu conceito e reflexos na atuação dos litigantes.

Ao fim, pretendeu-se estabelecer critérios a serem analisados pelo magistrado ao controlar a validade convenções processuais firmadas por vulneráveis.

Para tanto, foi utilizado o método dedutivo, para, a partir do estudo doutrinário e reflexões sobre autorregramento da vontade, convenções processuais e vulnerabilidade dos litigantes, tirar conclusões específica sobre como deve ser realizado o controle de validade, pelo magistrado, das convenções processuais firmadas por vulneráveis.

\section{AUTORREGRAMENTO DA VONTADE NO PROCESSO CIVIL BRASILEIRO: ASPECTOS ELEMENTARES}

A possibilidade de as partes negociarem aspectos procedimentais nada mais é do que um reflexo do princípio do autorregramento da vontade no Processo Civil. Portanto, inicialmente, estudar-se-á as implicações do princípio do autorregramento da vontade no Direito Processual Civil, considerando, principalmente, a trajetória evolutiva da ciência processual, o advento do neoprocessualismo e as inovações trazidas pelo Código de Processo Civil de 2015. Por fim, encerrar-se-á este tópico com o estudo sobre os negócios jurídicos processuais, com destaque à cláusula geral de negociação processual, instituída pelo artigo 190 da atual legislação processual.

\subsection{O Autorregramento da Vontade no Processo Civil}

Para melhor visualização do autorregramento da vontade no Processo Civil, mister se faz esboçar um panorama da evolução do Direito Processual Civil brasileiro. Isso porque o modelo processual que vigora hoje - denominado neoprocessualismo ou formalismo- 
valorativo - está estritamente relacionado à incidência do autorregramento da vontade no processo e somente pode ser verdadeiramente compreendido a partir de uma análise das transformações ocorridas ao longo do tempo. Nesse sentido, ensina José Bedaque que essa transformação "se apresenta como um dos fatores determinantes para compreender, na atualidade, as diretrizes mais amplas do Direito Processual Civil como um todo"2.

Até meados do século XIX, não havia que se falar em Direito Processual Civil. Isso porque vigorava o entendimento de ser o direito de ação a possibilidade de postular em juízo a reparação de um direito subjetivo material, quando este era violado ${ }^{3}$. Esse período denominado "sincretismo", pela doutrina - vigorou até 1868, quando a obra "Teoria dos Pressupostos Processuais e das Exceções Dilatatórias”, de autoria de Oskar von Büllow, marcou a o início de uma nova fase, em que se reconheceu a autonomia do Direito Processual como ciência, em razão, principalmente, da difusão da existência da chamada relação jurídica processual ${ }^{4}-5$.

Ocorre que a segunda fase, entusiasmada com o desenvolvimento técnico da ciência processual, acabou por distanciar o processo da realidade social. ${ }^{6}$ Assim, referida fase, denominada "autonomista", foi também superada, dando lugar ao chamado “instrumentalismo". Esta terceira fase metodológica processual foi agraciada com o amplo desenvolvimento científico atingido pelo Direito Processual na fase anterior, e somou a isso a preocupação em atender aos interesses sociais, tendo por objetivo final a pacificação social. Pode-se dizer, portanto, que o processo passa a ser "um instrumento a serviço da paz social".

Aliás, relevante destacar, nesse sentido, que a pacificação social, mesmo na vigência do Estado Liberal, já era reconhecida como uma responsabilidade estatal. Com o advento do Estado Social, o objetivo do processo foi reinterpretado, passando a significar não só a mera resolução de conflitos, como também, a realização de justiça ${ }^{8}$. Isso quer dizer que o interesse

\footnotetext{
${ }^{2}$ BEDAQUE, José Roberto dos Santos. Direito e processo: a influência do direito material sobre o processo. 2. ed. São Paulo: Malheiros, 2001. p. 75.

${ }^{3}$ CINTRA, Antonio Carlos de Araújo; GRINOVER, Ada Pellegrini; DINAMARCO, Cândido Rangel. Teoria geral do processo. 29. ed., rev. e atual. São Paulo: Malheiros, 2013. p. 51

${ }^{4}$ LUCCA, Rodrigo Ramina de. Liberdade, autonomia e convenções processuais. In: CABRAL, Antonio do Passo; NOGUEIRA, Pedro Henrique (Coord.). Negócios processuais. Tomo 2. Salvador: JusPodivm, 2020, p. 22.

${ }^{5}$ CINTRA, GRINOVER, DINAMARCO, 2013, p. 51

${ }^{6}$ CINTRA, GRINOVER, DINAMARCO, 2013, p. 52

${ }^{7}$ CINTRA, GRINOVER, DINAMARCO, 2013, p. 50

${ }^{8}$ CINTRA, GRINOVER, DINAMARCO, 2013, p. 33
} 
público da pacificação social, numa visão instrumentalista do processo, sobrepõe-se aos interesses individuais, permitindo a mitigação da autonomia da vontade, de forma que uma das partes não prejudique a outra indevidamente 9 .

Apesar de louvável a nova tendência processual, a fase instrumentalista colocou a jurisdição em posição de destaque na teoria do processo civil pois, ao romper com a visão liberal do processo, o protagonismo do juiz foi reforçado ${ }^{10}$, fazendo com que este período fosse marcado por um intenso publicismo. Nesse sentido, o Código de Processo Civil de 1973 atribuiu ao juiz poderes demasiadamente amplos quando comparados com os poderes que as partes detinham ${ }^{11}$.

Ora, não se nega a importância do publicismo processual. De fato, o processo interessa ao Estado, ao passo que a atividade jurisdicional reflete em toda a sociedade, em razão de sua função pacificadora. No entanto, o hiperpublicismo, conforme denominação crítica da doutrina, acaba por prejudicar a atuação dos principais interessados diretos no processo, quais sejam, as partes, na medida em que, ao transformar o processo, antes "coisa da parte", em "coisa do Estado", acabou-se por afastar o protagonismo dos sujeitos parciais, agora conferido ao juiz, tornando o processo, pois, uma "coisa sem partes"12.

Nesse sentido, vale colacionar a marcante afirmação de Robson Godinho, que entende que "a história do estudo da autonomia científica do processo civil é também a história da hipertrofia dos poderes dos juízes e da atrofia da autonomia das partes." ${ }^{13}$ Esse cenário, entretanto, vem sendo modificado nos últimos anos, em razão, especialmente, do advento do já citado neoconstitucionalismo. A necessidade de interpretação de normas conforme a Constituição Federal não deixou de fora o Direito Processual Civil. Ainda na vigência do Código de Processo Civil de 1973, ganhou forças o entendimento de que legislação

\footnotetext{
${ }^{9}$ DINAMARCO, Cândido Rangel. A instrumentalidade do processo. 14. ed., rev. e atual. São Paulo: Malheiros, 2009. p. 63.

${ }^{10}$ CUNHA, Leonardo Carneiro. Negócios Jurídicos Processuais no Processo Civil Brasileiro. In: CABRAL, Antonio do Passo; NOGUEIRA, Pedro Henrique (Coord.). Negócios processuais. Tomo 1. 2 ed. Salvador: JusPodivm, 2016. p. 48.

${ }^{11}$ REDONDO, Bruno Garcia. Negócios processuais: necessidade de rompimento radical com o sistema do CPC/1973 para a adequada compreensão da inovação do CPC/2015. In: CABRAL, Antonio do Passo; NOGUEIRA, Pedro Henrique (Coord.). Negócios processuais. Tomo 1. 2 ed. Salvador: JusPodivm, 2016. p. 358-359.

${ }^{12}$ LUCCA, 2020. p. 24

${ }^{13}$ GODINHO, Robson Renault. A possibilidade de negócios jurídicos processuais atípicos em matéria probatória. In: In: CABRAL, Antonio do Passo; NOGUEIRA, Pedro Henrique (Coord.). Negócios processuais. Tomo 1. 2 ed. Salvador: JusPodivm, 2016. p. 545.
} 
processual deveria ser interpretada conforme as normas e princípios constitucionais.

Tal fenômeno, em âmbito processual, é denominado neoprocessualismo ou formalismo-valorativo ${ }^{14}$, tratando-se apenas de variação terminológica. Nessa quarta fase metodológica processual, pacifica-se o entendimento de que a jurisdição ${ }^{15}$, de fato, não mais pode ser a protagonista do processo, pois isso iria de encontro à "dimensão essencialmente participativa que a democracia logrou alcançar na teoria do direito constitucional hodierno"16.

Isso porque um dos reflexos da Constituição Federal no processo civil foi justamente a imposição da democratização em âmbito processual, que se traduz na necessidade da efetiva participação dos sujeitos processuais, a qual, aliás, é pressuposto para que o processo seja considerado justo ${ }^{17}$. O processo deve ser, portanto, um ambiente propício para que as partes exercitem seu poder ${ }^{18}$.

O neoprocessualismo institui um modelo cooperativo de processo, o qual deve ser fundado no diálogo entre os sujeitos processuais ${ }^{19}$, objetivando, ao final, uma efetiva e justa prestação jurisdicional ${ }^{20}$. Destaque-se que a cooperação entre os sujeitos não é apenas um entendimento doutrinário, tendo sido positivada no artigo $6^{\circ}$ do Código de Processo Civil de 2015

Nesse sentido, insta destacar a necessidade de implementação de um contraditório efetivo, de forma a garantir o diálogo entre os sujeitos processuais. A participação dos sujeitos somente se efetiva mediante o exercício do direito fundamental ao contraditório,

\footnotetext{
${ }^{14}$ Eduardo Cambi e Fredie Didier são adeptos à denominação "neoprocessualismo", enquanto Daniel Mitidiero, por exemplo, se refere à fase processual como "formalismo valorativo". Didier explica que prefere o termo "neoprocessualismo" em razão da similaridade com o termo "neoconstitucionalismo" (DIDIER JR., Fredie. Curso de Direito Processual Civil, vol. I, 12 ed., Salvador: JusPodivm, 2010, p. 28). Já Daniel Mitidiero entende que a terminologia mais adequada seria "formalismo-valorativo" pois esta expressaria melhor as características e necessidade do processo civil, remetendo à ideia de que um "processo justo só pode ser concebido mediante a normatização e posterior concordância prática entre os valores igualdade, participação, efetividade e segurança, visando ao alcance do valor justiça" (MITIDIERO, Daniel. Colaboração no Processo Civil: pressupostos sociais, lógicos e éticos. 2. ed. São Paulo: Revista dos Tribunais, 2011. p. 52)

${ }^{15}$ Nesse sentido: "[...] a jurisdição não pode mais ser colocada como centro da teoria do processo civil." MITIDIERO, Daniel. Colaboração no Processo Civil: pressupostos sociais, lógicos e éticos. 2. ed. São Paulo: Revista dos Tribunais, 2011. p. 48

${ }^{16}$ MITIDIERO, Daniel. Colaboração no Processo Civil: pressupostos sociais, lógicos e éticos. 2. ed. São Paulo: Revista dos Tribunais, 2011. p. 48

${ }^{17}$ OLIVEIRA, Carlos Alberto Alvaro de; MITIDIERO, Daniel. Curso de Processo Civil. vol. I. São Paulo: Atlas, 2010, p. 16.

${ }^{18}$ RIBEIRO, Darci Guimarães. O papel do processo na construção da democracia: para uma nova definição de democracia participativa. In: Da tutela jurisdicional às formas de tutela. Porto Alegre: Livraria do Advogado, 2010, p. 105

${ }^{19}$ MITIDIERO, 2011.p. 86.

${ }^{20}$ CAMBI, 2011, p. 116
} 
devendo este ser entendido como o "direito a influenciar a formação da decisão jurisdicional" 21 . Tanto é que o artigo 10 da lei processual determina que o juiz permita a manifestação das partes antes de tomar qualquer decisão, até mesmo sobre matérias sobre as quais está autorizado a decidir de ofício.

O modelo processual instituído, portanto, preza pela participação efetiva de todos os sujeitos processuais. No entanto, para fins do presente trabalho, interessa os amplos poderes concedidos às partes, resultado, aliás, da maturação da ciência processual, que não mais se divide rigidamente entre publicismo e privatismo. $\mathrm{O}$ atual momento processual materializa o equilíbrio encontrado entre as duas vertentes, passando o processo a ser entendido como "coisa com partes". Isso significa, portanto, que as "conquistas do publicismo não excluem o respeito ao autorregramento da vontade das partes" 22 .

E é nesse cenário que surge o Código de Processo Civil de $2015^{23}$, materializando em seu texto tanto a relevância dos preceitos constitucionais ${ }^{24}$, replicando na lei processual princípios fundamentais, quanto a necessidade de participação e cooperação entre todos os sujeitos processuais, com especial destaque, aos sujeitos parciais, os quais são tidos como os verdadeiros protagonistas do processo. Daí extrai-se, pois, a incidência do autorregramento da vontade no Direito Processual Civil.

Segundo entendimento de Fredie Didier Jr., o autorregramento da vontade no processo civil pode ser considerado um subprincípio, derivado do princípio da liberdade ${ }^{25}$. Nessa linha, afirma o autor que a liberdade das partes é fundamental para o escorreito desenvolvimento processual em contraditório, posto que não há que se falar em democratização e colaboração processual sem o efetivo exercício da liberdade. Aliás, falar-se em processo sem liberdade remete a tempos autoritários, o qual, conforme visto, já foi (ou está quase) superado. ${ }^{26}$

Portanto, da análise do Código de Processo Civil de 2015, extraem-se diversos dispositivos que corroboram a primazia do autorregramento da vontade no modelo

\footnotetext{
${ }^{21}$ MITIDIERO, 2011, p. 150.

22 GODINHO, 2016, p. 546-547.

${ }^{23}$ GODINHO, 2016, p. 548.

${ }^{24}$ Evidenciada por seu artigo $1^{\circ}$, que dispõe que "o processo civil será ordenado, disciplinado e interpretado conforme os valores e as normas fundamentais estabelecidos na Constituição da República Federativa do Brasil, observando-se as disposições deste Código."

${ }^{25}$ DIDIER JR., Fredie. Principio do respeito ao autorregramento da vontade no processo civil. p. 18. In: DIDIER JR., FREDIE. Ensaios sobre os negócios jurídicos processuais. Salvador: Editora JusPodivm, 2018. p. 17-23.

${ }^{26}$ DIDIER JR., 2018, p. 19.
} 
processual hodierno. Além dos já citados dispositivos que impõem a cooperação e o contraditório, há vários institutos que materializam a liberdade no processo.

Logo no início do texto legislativo, verifica-se o incentivo à autocomposição (artigo $3^{\circ}, \S 3^{\circ}$ ), que é confirmado ao longo do Código (verbi gratia, artigos 165, 334 e 381). Ademais cabe às partes definir o objeto do litígio e dos recursos, bem como, há previsão legal de realização do saneamento de forma cooperativa (artigo 357), podendo as partes apresentar delimitação de fato e direito consensual. Por fim, merece especial destaque a ampla possibilidade de realização de negócios processuais, ou seja, as partes são autorizadas a convencionar sobre o procedimento, adequando-o à lide, de modo a melhor solucioná-la.

Frise-se que a negociação processual não é uma novidade legislativa, tendo em vista que, ainda no Código de Processo Civil de 1973, já era possível a modificação consensual do procedimento ${ }^{27}$. No entanto, o Código de Processo Civil de 2015, além de ampliar o rol dos negócios processuais típicos (veja-se, por exemplo, o já mencionado saneamento cooperativo), instituiu uma cláusula geral de negociação processual, autorizando as partes a modificar o procedimento e convencionar sobre seus ônus, poderes, faculdades e deveres processuais.

Tal possibilidade, tipificada pelo artigo 190 do diploma processual, talvez possa ser considerada a mais marcante materialização do autorregramento da vontade no processo civil e, por isso, dedicar-se-á o tópico seguinte a seu estudo.

\subsection{A Cláusula Geral de Negociação Atípica no Código de Processo Civil}

Diz-se que o artigo 190 do Código de Processo Civil é uma cláusula geral de negociação processual pois autoriza a realização de negócios atípicos, seguindo a mesma lógica aplicada, no Direito Civil, à atipicidade dos contratos ${ }^{28}$. Significa dizer, portanto, que preenchidos os requisitos do referido dispositivo, as partes podem convencionar amplamente sobre o procedimento e sobre seus ônus, poderes, faculdades e deveres processuais.

Insta mencionar que há quem diga que a possibilidade de negociação processual atípica

\footnotetext{
${ }^{27}$ Veja-se alguns exemplos de negócios processuais típicos previsto pelo Código de Processo Civil de 1973: suspensão convencional do processo, cláusula de eleição de foro e convenção sobre o ônus da prova.

${ }^{28}$ Art. 425. É lícito às partes estipular contratos atípicos, observadas as normas gerais fixadas neste Código.
} 
não é uma novidade legislativa ${ }^{29}$, pois entendem que o artigo 158 do código revogado ${ }^{30}$ já permitia interpretação a respeito da atipicidade da negociação processual ${ }^{31}$. Reforça tal corrente o fato de que o referido dispositivo revogado possui a exatamente a mesma redação do artigo 200 do atual diploma legal processual ${ }^{32}$. Nessa linha, Jaldemiro Ataíde entende que a principal alteração foi a abrangência da negociação processual, posto que a recente lei processual reduziu normas antes cogentes, as quais funcionam como um limite da validade dos negócios jurídicos. ${ }^{33}$

No entanto, mesmo aqueles que já entendiam pela possibilidade da negociação atípica durante a vigência do Código de Processo Civil de 1973 exaltam o dispositivo atual. Isso porque a negociação processual atípica não era aceita por boa parte da doutrina, em razão do entendimento no sentido de que as partes não poderiam convencionar sobre os efeitos dos atos praticados, tendo em vista que esses somente poderiam decorrer da lei ou de intervenção judicial ${ }^{34}$. Aliás, tais premissas derivam justamente da já mencionada supremacia da jurisdição, característica de um modelo público de processo. A ideia de que as partes poderiam alterar o procedimento, vinculando o juiz à sua vontade, era absolutamente conflitante com protagonismo conferido ao magistrado ${ }^{35}$.

Ocorre que, com a positivação implementada pelo Código de Processo Civil de 2015, até mesmo aqueles que se posicionavam contrários à prática da adequação procedimental não tiveram escolha senão reconhecer sua absoluta legalidade.

Pois bem. O estudo sobre os negócios processuais é extremamente amplo. No entanto, importa para o presente trabalho apenas compreender em que consistem as convenções processuais e quais suas limitações, sempre à luz do princípio do autorregramento da vontade e da liberdade.

\footnotetext{
${ }^{29}$ TUCCI, José Rogério Cruz e. Natureza e objeto das convenções processuais. p. 27. In: CABRAL, Antonio do Passo; NOGUEIRA, Pedro Henrique (Coord.). Negócios processuais. Tomo 1. 2 ed. Salvador: JusPodivm, 2016. p. 23-29

${ }^{30}$ Art. 158. Os atos das partes, consistentes em declarações unilaterais ou bilaterais de vontade, produzem imediatamente a constituição, a modificação ou a extinção de direitos processuais.

31 CUNHA, 2016, p. 57.

32 Art. 200. Os atos das partes consistentes em declarações unilaterais ou bilaterais de vontade produzem imediatamente a constituição, modificação ou extinção de direitos processuais.

${ }^{33}$ ATAIIDE JUNIOR, Jaldemiro Rodrigues. Negócio jurídicos materiais e processuais - existência, validade e eficácia - campo-invariáriel e campos-dependentes: sobre os limites dos negócios jurídicos processuais. In: CABRAL, Antonio do Passo; NOGUEIRA, Pedro Henrique (Coord.). Negócios processuais. Tomo 1. 2 ed. Salvador: JusPodivm, 2016. p. 257.

${ }^{34}$ CUNHA, 2016, p. 48.

${ }^{35}$ CUNHA, 2016, p. 49-50.
} 
Negócios processuais, num paralelo com os negócios jurídicos, são atos decorrentes da manifestação de vontade unilateral, bilateral ou plurilateral das partes, pelos quais constitui-se, modifica-se ou extingue-se determinada situação processual, ou altera-se o procedimento $^{36}$. Veja-se, portanto, que o negócio processual pode derivar de apenas uma manifestação de vontade. O que nos interessa, no entanto, são as chamadas convenções processuais, ou seja, os negócios processuais bilaterais ou plurilaterais. ${ }^{37}$

Nos termos do artigo 190 do Código de Processo Civil, quando o processo versar sobre direitos que admitam autocomposição e desde que as partes sejam plenamente capazes, é lícita a realização de convenções sobre o procedimento e sobre seus ônus, poderes, faculdades e deveres processuais.

É importante ressalvar que, apesar do paralelo com os negócios jurídicos, a possibilidade de negociação processual não significa a privatização do processo. O processo continua sendo ramo do Direito Público, regido pelo Código de Processo Civil. A lei processual tão somente reconhece que, sendo as partes as maiores interessadas no processo, cujo objetivo é tutela de seu direito material, a titularidade de determinadas situações processuais é tão somente delas e, portanto, autoriza-as a regulamentar tais situações conforme melhor lhes convier ${ }^{38}$. Reconhece-se, assim, o interesse privado no processo. ${ }^{39}$

Insta mencionar que, de acordo com Antonio do Passo Cabral, não é o princípio do autorregramento da vontade das partes, por si, que possibilita a negociação processual. Isso porque, em razão da natureza pública do processo - que enseja maior limitação na liberdade negocial - é preciso a combinação de outros dois princípios para justificar a autonomia dos sujeitos parciais: o princípio dispositivo e o princípio do debate. ${ }^{40}$

O princípio do dispositivo possibilita que as partes disponham e renunciem determinados direitos, impondo ao Estado o dever de respeitar suas decisões. A aplicação de tal princípio ao processo se deve ao fato de que, ao reconhecer os interesses individuais das partes no processo, a legislação processual confia a elas a efetivação de seus direitos ${ }^{41}$. Vejase, portanto, o equilíbrio necessário entre o interesse público e os interesses privados

\footnotetext{
${ }^{36}$ CABRAL, Antonio do Passo. Convenções processuais. 2. ed. Salvador: JusPodivm, 2018. p. 52.

${ }^{37}$ CABRAL, 2018. p. 54.

${ }^{38}$ REDONDO, 2016, p. 362-363.

${ }^{39}$ CABRAL, 2018. p. 152

${ }^{40}$ CABRAL, 2018. p. 158

${ }^{41}$ CABRAL, 2018. p. 154
} 
incidentes no processo ${ }^{42}$.

Nesse sentido, o princípio do debate pode ser considerado o "princípio dispositivo em sentido processual", que se traduz na valorização da autonomia das partes no procedimento, em contraponto à ultrapassada hiper valorização da jurisdição e do Estado-juiz. É o princípio do debate que fundamenta o destaque dos sujeitos parciais na condução do procedimento ${ }^{43}$, bem como, que possibilita que as partes disponham e renunciem a determinados direitos fundamentais processuais ${ }^{44}$ e realizem negócios processuais.

Nessa esteira, a doutrina elencou algumas convenções processuais admissíveis ao elaborar os Enunciados 19 e 21 do Fórum Permanente de Processualistas Civis, tais como: pacto de impenhorabilidade, acordo de rateio de despesas processuais, dispensa consensual de assistente técnico, acordo para retirar o efeito suspensivo de recurso, acordo para não promover execução provisória, pacto de mediação ou conciliação extrajudicial prévia obrigatória, julgamento antecipado do mérito convencional, convenção sobre prova, redução de prazos processuais, dentre outros. É latente, portanto, a ampla possibilidade de modificação do procedimento.

No entanto, conforme já mencionado, a disposição sobre matéria processual encontra limitações no ordenamento jurídico. Se até mesmo em sede de direito privado há limitação ao autorregramento da vontade dos contratantes, em matéria processual, especialmente em se considerando o interesse público e as normas cogentes, as limitações serão significativamente mais intensas ${ }^{45}$. Saliente-se, nesse sentido, que a autonomia das partes e os limites impostos pela lei não são conflitantes, e sim complementares, posto que a limitação integra o próprio conceito da autonomia ${ }^{46}$.

O próprio artigo 190 já evidencia duas balizas legais à negociação processual: é necessário que o direito objeto da lide admita a autocomposição ${ }^{47}$ e as partes devem ser

\footnotetext{
${ }^{42}$ CABRAL, 2018. p. 155

${ }^{43}$ CABRAL, 2018. p. 157

${ }^{44}$ CABRAL, 2018. p. 158

${ }^{45}$ NOGUEIRA, Pedro Henrique. Sobre os Acordos de Procedimento no Processo Civil Brasileiro. p. 96. In: CABRAL, Antonio do Passo; NOGUEIRA, Pedro Henrique (Coord.). Negócios processuais. Tomo 1. 2 ed. Salvador: JusPodivm, 2016 p. 93-104

${ }^{46}$ CABRAL, 2018. p. 170.

${ }^{47} \mathrm{~A}$ impossibilidade de negociação recai apenas sobre direitos que não admitem autocomposição, não se confundido com direitos indisponíveis. Nesse sentido, veja-se redação do Enunciado 135 do Fórum Permanente de Processualistas Civis: A indisponibilidade do direito material não impede, por si só, a celebração de negócio jurídico processual"
} 
plenamente capazes. Quanto à capacidade, deve ser compreendida não só em seu aspecto civil. De fato, é preciso que a parte possua capacidade civil para negociar aspectos procedimentais. No entanto, é ainda preciso que o convenente possua capacidade de ser parte e de estar em juízo. Dentre as capacidades processuais, a única não essencial para a validação do negócio é a capacidade postulatória ${ }^{48}$.

Um outro limite à negociação processual são as matérias de ordem pública ${ }^{49}$. No entanto, há aqueles que entendem que matérias de ordem pública funcionam na proteção do jurisdicionado $^{50}$ e, sob tal argumento, relativizam a limitação da negociação ${ }^{51}$. Este, entretanto, não é objeto do presente estudo.

Além dessas hipóteses, o parágrafo único do artigo 190 elenca mais três situações em que o juiz poderá controlar a validade da convenção processual e, se for o caso, afastar sua aplicação: i) nos casos de nulidade; ii) quando houver inserção abusiva em contratos de adesão; iii) quando alguma parte se encontrar em manifesta situação de vulnerabilidade.

A redação do parágrafo único ${ }^{52}$, mais especificamente, o advérbio "somente", confirma que as convenções processuais se pressupõem válidas ${ }^{53}$ e há restritas hipóteses de invalidação do negócio. Tal dispositivo, portanto, evidencia o "equilíbrio entre os interesses públicos e privados", na medida em que "as convenções são amplamente permitidas" e "atividade de controle do juiz restringe-se a verificar, a posteriori ${ }^{54}$, se as partes extrapolaram o espaço que o ordenamento jurídico lhes atribuiu para atuar." 55

Pois bem. Como a terceira hipótese de invalidação da convenção processual elencada no parágrafo único é objeto específico da presente pesquisa, dedicar-se-á o próximo tópico para seu estudo.

\footnotetext{
${ }^{48}$ CABRAL, 2018. p. 313-317.

49 ATAÍDE JUNIOR, 2016, p. 275.

${ }^{50}$ LUCCA, 2020, p. 22.

${ }^{51}$ Nesse sentido, Fredie Didier Jr. entende ser possível a negociação processual para ignorar a coisa julgada anterior e propor nova ação para discutir o mesmo tema (DIDIER JR., Fredie. Negócios jurídicos processuais atípicos no CPC-2015. In: DIDIER JR., Fredie. Ensaios sobre os negócios jurídicos processuais. Salvador: Editora JusPodivm, 2018. p. 31

52 Art. 190. Parágrafo único. De ofício ou a requerimento, o juiz controlará a validade das convenções previstas neste artigo, recusando-lhes aplicação somente nos casos de nulidade ou de inserção abusiva em contrato de adesão ou em que alguma parte se encontre em manifesta situação de vulnerabilidade.

${ }^{53}$ CABRAL, 2018. p. 163.

${ }^{54}$ A redação do Enunciado 133 do Fórum Permanente de Processualistas Civil corrobora tal afirmação: "Salvo nos casos expressamente previstos em lei, os negócios processuais do art. 190 não dependem de homologação judicial."

${ }^{55}$ CABRAL, 2018. p. 259
} 


\section{VULNERABILIDADE NO PROCESSO CIVIL: CONCEITOS E DELINEAÇÕES}

O estudo sobre a vulnerabilidade se justifica ao passo que, como mencionado, a "manifesta" vulnerabilidade da parte pode ensejar a invalidação da convenção processual pelo juiz. Portanto, imprescindível realizar um breve estudo sobre o que seja a vulnerabilidade e, em especial, seus reflexos na atuação processual.

Para tanto, num primeiro momento, necessário tecer breves comentários sobre a igualdade e sua incidência no processo civil. Em seguida, passa-se à análise da vulnerabilidade processual, tendo por base, em especial, a pesquisa desenvolvida por Fernanda Tartuce.

\subsection{Princípio da Igualdade e seus Reflexos no Processo}

A relevância da análise do princípio da igualdade, no presente trabalho, evidencia-se, pois, conforme ensina Konrad Hesse, a autonomia privada e a liberdade "presuponen una situación jurídica y fáctica aproximadamente igual de los interesados. Donde falta tal presupuesto, y la autonomia privada de uno conduce a la falta de liberdad del outro, desaparece todo fundamento y traspasa todo limite" ${ }^{, 56}$. Significa dizer, portanto, que a igualdade é um pressuposto da liberdade ${ }^{57}$.

Quando se fala em igualdade, nunca é demais reforçar que a igualdade tida por direito fundamental em nossa Constituição Federal não significa o tratamento igualitário entre os sujeitos perante a lei, justamente porque seria flagrante violação à isonomia a imposição dos mesmos direitos e deveres a indivíduos que, por sua própria natureza, são desiguais. ${ }^{58}$

O mero tratamento paritário perante a lei (igualdade formal) dá lugar ao reconhecimento da igualdade material ou substancial ${ }^{59}$. Esta se diferencia daquela especialmente no que diz respeito à atuação estatal, ao passo que aquela impunha ao Estado mero dever de abstenção nas relações privadas, enquanto que nesta, o Estado é obrigado a

\footnotetext{
${ }^{56}$ HESSE, Konrad. Derecho constitucional y derecho privado. Madrid: Civitas, 2001. p. 78-79.

${ }^{57}$ PRATA, Ana. A tutela constitucional da autonomia privada. Coimbra: Livraria Almedina, 1982. p. 86

${ }^{58}$ KELSEN, Hans. Teoria pura do direito. 6. ed. São Paulo: Martins Fontes, 1998. p. 158

${ }^{59}$ BORGES, 2005. p. 67
} 
fazer $^{60}$, ou seja, deve garantir a promoção da igualdade social fática, não se contentando mais com o mero reconhecimento legal da igualdade. ${ }^{61}$

Os desdobramentos decorrentes da busca por igualdade material refletiram no Direito Material principalmente no que se refere à autonomia da vontade. Passou-se a entender que a autonomia privada deixaria de ser motivada por uma vontade livre quando uma das partes estivesse em condição de desigualdade econômica ou social ${ }^{62}$. Foi partindo desse princípio que se elaborou, verbi gratia, o Código de Defesa do Consumidor e as leis trabalhistas, com claro intento de proteger a parte considerada mais fraca na relação jurídica, de forma a garantir o exercício de sua liberdade e autonomia. ${ }^{63}$

A igualdade material, portanto, está intimamente ligada à concepção de liberdade positiva que, nas palavras de Norberto Bobbio, é a "situação na qual um sujeito tem a possibilidade de orientar seu próprio querer no sentido de uma finalidade, de tomar decisões, sem ser determinado pelo querer de outros", sendo equivalente, portanto, à verdadeira autonomia. ${ }^{64}$ Assim, nas relações privadas, quanto maior a desigualdade entre as partes, maior será a mitigação da autonomia da vontade, tendo como perspectiva a proteção dos direitos fundamentais da parte mais fraca. ${ }^{65}$

Todas as reflexões alhures refletem diretamente no processo. Da mesma forma que o Estado, com base no espectro do Estado Social, deve buscar a mitigação das desigualdades para possibilitar uma negociação paritária, não mais se abstendo de interferir nas relações privadas, o juiz passa a ter, no processo, função similar, na medida em que não mais se admite um juiz inerte - sob justificativa da imparcialidade -, sendo imprescindível que o magistrado considere eventuais desigualdades entre os litigantes, sem que isso signifique atuação parcial ${ }^{66}$. Aliás, haveria parcialidade se o juiz simplesmente ignorasse as

\footnotetext{
${ }^{60}$ MIRANDA, Pontes de. Democracia, liberdade, igualdade: os três caminhos. 1. ed. Campinas: Bookseller, 2002. p. 621

${ }^{61}$ SARMENTO, 2006, p. 19

${ }^{62}$ BORGES, 2005. p. 67

${ }^{63}$ BORGES, 2005. p. 70

${ }^{64}$ BOBBIO, Norberto. Igualdade e liberdade. Tradução de Carlos Nelson Coutinho. 2. ed. Rio de Janeiro: Ediouro, 1997. p. 51

${ }^{65}$ CAMBI, 2011. p. 36

${ }^{66}$ Cabe aqui transcrever a lição de Barbosa Moreira: "A transição do liberalismo individualista para o "Estado social de direito" assinala-se, como é sabido, por substancial incremento da participação dos órgãos públicos na vida da sociedade. Projetado no plano processual, traduz-se o fenômeno pela intensificação da atividade do juiz, cuja imagem já não se pode comportar no arquétipo do observador distante e impassível da luta entre as partes, simples fiscal incumbido de vigiar-lhes o comportamento, para assegurar a observância das "regras do jogo" e, no fim, proclamar o vencedor. Não menos que na economia, a emergência do "social" também no
} 
disparidades entre os sujeitos parciais. ${ }^{67}$

Isto posto, o ponto de partida para o estudo da igualdade no processo civil é a paridade de armas, tida como projeção do princípio da igualdade, e necessária para o exercício de um contraditório $^{68}$ equilibrado ${ }^{69}$ e substancial. Portanto, admite-se a criação de normas ou adoção de medidas, pelo juiz, que assegurem a paridade de armas entre os litigantes, de forma a reequilibrar eventuais desigualdades existentes fora do processo, evitando que estas prejudiquem sua atuação em Juízo. ${ }^{70}$

No Código de Processo Civil de 1973, já havia expressamente a imposição, ao juiz, do dever de assegurar às partes igualdade de tratamento ${ }^{71}$, sendo tal dispositivo, na visão de Barbosa Moreira, um reflexo do princípio da isonomia ${ }^{72}$, consubstanciado na igualdade perante a lei ${ }^{73}$. O Código de Processo Civil de 2015, além de transpor o referido dispositivo para o capítulo destinado às suas normas fundamentais, implementou a sua redação ${ }^{74}$, o que evidencia a preocupação do legislador processual com a igualdade material em sede de processo civil.

No entanto, a paridade de armas, também denominada "igualdade no processo", não esgota os reflexos da igualdade no processo civil. Importa também considerar a necessidade

processo derrui o império do laisser faire. Recusa-se aos litigantes a possibilidade de marcar soberanamente o compasso da marcha processual; equaciona-se em novos termos o capital problema da "divisão de tarefas" entre as partes e o órgão de jurisdição." MOREIRA, José Carlos Barbosa. A função social do processo civil moderno e o papel do juiz e das partes na direção e na instrução do processo. Revista de processo. vol. 37/1985. p. 145

${ }^{67}$ MARINONI, Luiz Guilherme. Novas linhas do processo civil. 4. ed. São Paulo: Malheiros, 2000. p. 102

${ }^{68}$ Tem-se por contraditório a possibilidade de que as partes "influenciem na descoberta do direito", sendo necessário, para tanto, "que se conceba, como um valor político, a igualdade entre as pessoas do processo (...)". MITIDIERO, 2011. p. 92.

${ }^{69}$ DINAMARCO, 2009. p. 160-161

${ }^{70}$ CINTRA, GRINOVER, DINAMARCO, 2013, p. 63.

${ }^{71}$ Art. 125. O juiz dirigirá o processo conforme as disposições deste Código, competindo-lhe: I - assegurar às partes igualdade de tratamento;

${ }^{72}$ Em artigo publicado durante a vigência do Código de Processo Civil de 1973, Rafael Barbosa e Murílio Maia defendiam que "a aplicação do princípio da isonomia previsto no art. 125 do CPC (LGL \1973\5) somente poderá ocorrer após análise comparativa dos poderes das partes. Quando os litigantes adversários tiverem poderes grandes e proporcionais - faz-se referência aqui ao poder econômico, processual e probatório -, o magistrado poderá se conformar com a perspectiva formal da igualdade e com postura mais cautelosa e passiva no tramitar processual.” BARBOSA, Rafael Vinheiro Monteiro; MAIA, Maurílio Casas. Isonomia dinâmica e vulnerabilidade no direito processual civil. Revista de Processo. vol. 230/2014. p. 351.

${ }^{73}$ MOREIRA, José Carlos Barbosa. A função social do processo civil moderno e o papel do juiz e das partes na direção e na instrução do processo. Revista de processo. vol. 37/1985. p. 140.

${ }^{74}$ Art. $7^{\circ}$ É assegurada às partes paridade de tratamento em relação ao exercício de direitos e faculdades processuais, aos meios de defesa, aos ônus, aos deveres e à aplicação de sanções processuais, competindo ao juiz zelar pelo efetivo contraditório. 
da chamada "igualdade ao processo", consubstanciada na influência que situações pessoais das partes, externas ao processo, podem surtir nele, ensejando eventual prejuízo aos litigantes desfavorecidos. ${ }^{75}$

Feitas tais considerações, passa-se à análise da vulnerabilidade no processo civil.

\subsection{Vulnerabilidade no Processo Civil}

A vulnerabilidade, em sentido amplo, pode ser traduzida na suscetibilidade da pessoa a sofrer um dano, em decorrência de sua condição subjetiva. ${ }^{76}$ No Direito, na linha do neoconstitucionalismo, a vulnerabilidade serve como um mecanismo de adequação “dogmática tradicional do direito privado à ordem constitucional que privilegia a pessoa humana, no sentido da despatrimonialização do direito civil, rumo a uma sociedade mais livre, justa e solidária"77.

Aplicada ao processo, a vulnerabilidade é conceituada, por Fernanda Tartuce, como sendo "a suscetibilidade do litigante que o impede de praticar os atos processuais em razão de uma limitação pessoal involuntária ensejada por fatores de saúde e/ou de ordem econômica, informacional, técnica ou organizacional"78. Portanto, no sentindo de buscar a "igualdade ao processo", o juiz deve estar atento a possíveis vulnerabilidades que acometem o litigante, e atuar de forma a evitar prejuízos decorrentes de sua condição desfavorável ${ }^{79}$. Uma postura mais ativa do juiz é exigível para que, ao perceber disparidades entres as partes, atue de forma a possibilitar que as desigualdades externas ao processo não reflitam no deslinde da causa ${ }^{80}$.

Nesse sentido, a autora entende que, apesar de a vulnerabilidade dever ser aferida pela análise individual de cada litigante, é necessário elencar alguns fatores objetivos que podem

\footnotetext{
${ }^{75}$ ABREU, Rafael Sirangelo. A Igualdade e os Negócios Processuais. In: CABRAL, Antonio do Passo; NOGUEIRA, Pedro Henrique (Coord.). Negócios processuais. Tomo 1. 2 ed. Salvador: JusPodivm, 2016. p. 283

${ }^{76}$ BARBOSA, Rafael Vinheiro Monteiro; MAIA, Maurílio Casas. Isonomia dinâmica e vulnerabilidade no direito processual civil. Revista de Processo. vol. 230/2014. p. 143.

${ }^{77}$ KONDER, Carlos Nelson. Vulnerabilidade patrimonial e vulnerabilidade existencial: por um sistema diferenciador. Revista de Direito do Consumidor. vol. 99/2015. p. 101

${ }^{78}$ TARTUCE, Fernanda. Igualdade e vulnerabilidade no processo civil. Rio de Janeiro: Forense, 2012. p. 184.

${ }^{79}$ TARTUCE, 2012. p. 134.

${ }^{80}$ CAPPELLETTI, Mauro; GARTH, Bryant. Acesso à justiça. Porto Alegre: Fabris, 1988. p. 77
} 
ensejar a vulnerabilidade processual, para evitar subjetivismos inconvenientes ${ }^{81}$. Interessanos, para fins da presente pesquisa, as vulnerabilidades decorrentes da insuficiência econômica, óbices geográficos, dificuldades informacionais, técnicas e incapacidade organizacional.

A vulnerabilidade econômica (ou hipossuficiência) está atrelada à falta de recursos financeiros, que pode acabar prejudicando o efetivo acesso à justiça do jurisdicionado' na medida em que dificulta a prática de determinados atos processuais ${ }^{82}$. A Constituição Federal não só reconhece a vulnerabilidade econômica, como também impõe ao Estado o dever de fornecer assistência jurídica integral aos hipossuficientes ${ }^{83}$, assim como, o Código de Processo Civil trata sobre a gratuidade da justiça ${ }^{84}$.

Ainda assim, pessoas acometidas por tal vulnerabilidade podem acabar prejudicadas quando vão a Juízo em face daqueles que podem pagar para litigar, sem maiores prejuízos ${ }^{85}$, especialmente quando se considera a morosidade do Judiciário. A necessidade de obter o bem da vida no menor intervalo de tempo possível pode fazer a parte vulnerável desistir de um recurso que poderia lhe ser favorável, ou aceitar receber valor inferior ao da condenação, em troca da não interposição de recurso pela parte contrária ${ }^{86}$. Dessa forma, apesar de alguns esforços legislativos, as dificuldades econômicas da parte podem desigualá-las no processo.

Outro fator que enseja a vulnerabilidade da parte são os óbices geográficos intransponíveis ${ }^{87}$. Num passado não tão distante, antes da implementação dos processos eletrônicos, essa vulnerabilidade podia ser percebida mais facilmente. No momento atual, com a disseminação da tecnologia, muitos óbices geográficos, antes intransponíveis, deixaram de configuram um problema para o litigante. No entanto, ainda pode acontecer de pessoas em situação de extrema vulnerabilidade (acentuada por dificuldades financeiras)

\footnotetext{
${ }^{81}$ TARTUCE, 2012. p. 189

82 TARTUCE, 2012. p. 190.

83 TARTUCE, 2012. p. 191.

${ }^{84}$ Em seus artigos 98 a 102.

${ }^{85}$ CAPPELLETTI, GARTH, 1988, p. 21

${ }^{86}$ Nesse sentido: "Sabe a lugar-comum a observação de que o litigante de melhores recursos quase sempre tem mais fácil acesso a informações relevantes, está em condições mais favoráveis para armar-se de provas, utiliza os serviços de advogados mais competentes, e assim por diante. Ninguém ignora tampouco que ele pode resistir com menor sacrifício aos inconvenientes da longa duração dos pleitos, e até, eventualmente, daí tirar proveito para constranger o adversário a um acordo que este não aceitaria noutras circunstâncias.” MOREIRA, José Carlos Barbosa. A função social do processo civil moderno e o papel do juiz e das partes na direção e na instrução do processo. Revista de processo. vol. 37/1985. p. 141.
}

${ }^{87}$ TARTUCE, 2012. p. 193 
terem dificuldades de se locomover dentro da própria cidade, ou de poderem arcar com as custas de eventual viagem. Portanto, não se pode ignorar a vulnerabilidade geográfica.

Ainda, a vulnerabilidade do litigante pode se originar de deficiência informacional, decorrente tanto do desconhecimento sobre o direito material quanto processual, ou seja, o indivíduo pode não conhecer seu direito, não saber sobre sua extensão ou não saber como buscá-lo em juízo ${ }^{88}$. Isso porque, como se sabe, o ordenamento jurídico é repleto de termos técnicos incompreensíveis para leigos. Assim, a parte que sequer compreende os termos de um contrato não possui condições para objetá-lo. ${ }^{89}$ Ainda mais problemática pode ser a interpretação de normas procedimentais, as quais possuem "viés ainda mais técnico" 90 .

Ademais, a vulnerabilidade pode decorrer de dificuldades técnicas, que pode ser em tanto em razão da atuação do (ou ausência de) advogado, quanto à dificuldade de provar, em juízo, os fatos alegados ${ }^{91}$. A ausência de advogado, apesar de autorizada em determinados casos, não é aconselhável, justamente porque o ambiente processual é extremamente técnico e de difícil compreensão por pessoas leigas. As dificuldades probatórias, por outro lado, ganham relevância na medida em que, se a parte não conseguir comprovar determinado fato - nos casos, por exemplo, de prova de difícil produção - pode ter seu direito a determinado bem da vida negado. Nesse sentido, a possibilidade da distribuição dinâmica do ônus da prova pode mitigar a vulnerabilidade técnica da parte.

O último fator ensejador de vulnerabilidade processual é a incapacidade organizacional da parte, que se evidencia nos casos de "disparidades estruturais entre os litigantes" $" 92$. A vulnerabilidade organizacional é latente nos casos de disputas entre litigantes inexperientes e aqueles que litigam de forma frequente e organizada, como é o caso de grandes instituições financeiras e grandes escritórios de advocacia. Isso porque o litigante habitual acaba sendo mais eficiente e utiliza o sistema judicial para a satisfação dos próprios interesses $^{93}$.

Por fim, insta salientar que a vulnerabilidade processual pode não estar atrelada a nenhuma vulnerabilidade de ordem material. Por exemplo, o consumidor é tipo por

\footnotetext{
${ }^{88}$ TARTUCE, 2012. p. 198

${ }^{89}$ CAPPELLETTI, GARTH, 1988, p. 22

90 TARTUCE, 2012. p. 199

91 TARTUCE, 2012. p. 202.

92 TARTUCE, 2012. p. 208.

${ }^{93}$ CAPPELLETTI, GARTH, 1988, p. 25-28.
} 
vulnerável nas relações de consumo e, no processo, também poderá ser considerado vulnerável em razão de sua qualidade de consumidor. No entanto, é plenamente possível que uma pessoa não apresente nenhuma vulnerabilidade latente no âmbito dos negócios materiais, mas, no momento de sua atuação em juízo, seja acometida por alguma das vulnerabilidades anteriormente referidas. Seria o caso, por exemplo, de um empresário que não possui conhecimento mínimos sobre o Direito, podendo, pois, ser considerado um vulnerável informacional.

Tal diferenciação é relevante pois o que interessa, para fins do controle de validade do negócio processual a que se refere o parágrafo único do artigo 190 do Código de Processo Civil, é tão somente a vulnerabilidade processual.

\section{CONTROLE DE VALIDADE DAS CONVENÇÕES PROCESSUAIS FIRMADAS POR VULNERÁVEL}

Conforme dito, uma das hipóteses de não aplicação da convenção processual é a manifesta vulnerabilidade da parte. Há inúmeros estudos e posições doutrinárias sobre tal tema, mas é praticamente consenso que a vulnerabilidade da parte se insere no plano de validade da convenção processual ${ }^{94}$. No entanto, não há consenso sobre qual seria o elemento da validade do negócio atingido pela vulnerabilidade. Nesse sentido, há quem entenda que a vulnerabilidade enseja incapacidade negocial das partes ${ }^{95}$, e outros que defendem que a vulnerabilidade pode macular a manifestação da vontade ${ }^{96}$. Há, ainda, o entendimento de que a ausência de vulnerabilidade seria um requisito autônomo da validade da convenção

\footnotetext{
${ }^{94}$ ATAÍDE JUNIOR, 2016, p. 271-272. No mesmo sentido: DIDIER JR., Fredie. Negócios jurídicos processuais atípicos no CPC-2015. In: DIDIER JR., FREDIE. Ensaios sobre os negócios jurídicos processuais. Salvador: Editora JusPodivm, 2018. p. 34.

${ }^{95}$ Nesse sentido: "É a capacidade processual o requisito de validade exigido para a prática dos negócios processuais atípicos [...]. No caso, exige-se a capacidade processual negocial, que pressupõe a capacidade processual, mas não se limita a ela, pois a vulnerabilidade é caso de incapacidade processual negocial, como será visto adiante, que a princípio não atinge a capacidade processual geral - um consumidor é processualmente capaz, embora possa ser um incapaz processual negocial.” DIDIER JR., Fredie. Negócios jurídicos processuais atípicos no CPC-2015. p. 34. In: In: DIDIER JR., Fredie. Ensaios sobre os negócios jurídicos processuais. Salvador: Editora JusPodivm, 2018. p. 25-46.

${ }^{96}$ Esse é o entendimento de Jaldemiro Ataíde Junior: "Note-se que esses dois novos requisitos de validade (ao fim e ao caso, ambos resumem-se à vulnerabilidade de uma das partes) relacionam-se à perfeição da manifestação de vontade,63 estando, pois, ao lado dos vícios clássicos de vontade (erro, dolo, coação, estado de perigo, lesão).” ATAÍDE JUNIOR, 2016, p. 271-272.
} 
processual $^{97}$. Essa discussão, entretanto, será tratada em trabalho específico.

No que concerne à presente reflexão, insta compreender a razão pela qual a vulnerabilidade da parte pode ensejar a invalidação da convenção processual. Incialmente, faz-se necessário ter em mente que, assim como nas relações de direito material, no processo, as partes também podem estar em situações de desigualdade. Esse ponto, aliás, já foi tratado em tópico anterior. Assim, por óbvio, desigualdades refletirão no processo, mas, esse fato, por si, não pode ser causa de inaplicação da convenção processual.

Tanto é que, no âmbito do direito material, a desigualdades entre os contratantes não impede a formação válida do negócio jurídico. Não se nega, por exemplo, o direito de contratar do consumidor ou do empregado - isso sim seria um absurdo -, apenas há implementação de mecanismos de proteção ao contratante vulnerável ${ }^{98}$, tais como as normas protetivas do Código de Defesa do Consumidor e da legislação trabalhista. É disso que se trata o parágrafo único do artigo 190. Até mesmo porque, a convenção processual pode ser favorável ao litigante em situação de vulnerabilidade ${ }^{99}$. Portanto, pode-se afirmar que é preciso analise cuidadosa, já que não é sempre que a convenção será invalidada se uma das partes for vulnerável.

Explica-se. A possibilidade de invalidação do negócio encontra fundamento na necessidade de igualdade real entre os litigantes, na paridade de armas e na "igualdade ao processo". Pretende o legislador, ao possibilitar o controle de validade da convenção processual pelo juiz, evitar que as convenções prejudiquem a atuação processual do litigante vulnerável, com o objetivo, portanto, de reduzir eventuais desigualdades entre as partes ${ }^{100}$.

Destaque-se, entretanto, que o mero prejuízo ao litigante por uma estratégia processual malsucedida não merece a tutela prevista pelo parágrafo único do artigo $190^{101}$. Isso porque, sendo a liberdade também um direito fundamental, somente se admite sua relativização em casos excepcionais, para evitar o dano a outro direito fundamental ${ }^{102}$. Assim, da mesma forma que um contrato não será invalidado somente em razão do prejuízo do

\footnotetext{
${ }^{97}$ SOARES, Lara Rafaelle Pinho. A Vulnerabilidade na Negociação Processual Atípica. 2016, 185 f. Dissertação (Mestrado em Direito Público) - Universidade Federal da Bahia, Salvador, 2016.

${ }^{98}$ CABRAL, 2018. p. $218-219$

${ }^{99}$ CABRAL, 2018. p. 315 e 375.

${ }^{100}$ LUCCA, 2020, p. 39.

${ }^{101}$ ABREU, 2016, p. 298-299.

${ }^{102}$ LUCCA, 2020, p. 29.
} 
contratante - afinal, eventuais prejuízos fazem parte do jogo da negociação - a convenção processual não será afastada apenas por causar prejuízo ao litigante, desde que este, claro, esteja em condições de igualdade com o outro convenente ${ }^{103}$.

Feitas tais considerações, importa agora determinar quais critérios devem ser observados para que as convenções processuais firmadas por vulneráveis sejam invalidadas.

\subsection{Critérios para Invalidação da Convenção Processual Envolvendo Vulnerável}

A possibilidade de controle de validade da convenção processual, mostra-se condizente com novo modelo de processo, que preza pela igualdade material entre os litigantes. Destaque-se, entretanto, que o que se tutela é a igualdade no momento da realização da convenção. Isso porque, conforme dito, um litigante não vulnerável pode realizar convenção que o desfavoreça e desequilibre sua atuação no processo. No entanto, essa má escolha estratégica não merece proteção judicial, devendo as consequências serem suportadas pelo convenente ${ }^{104}$.

De forma a evitar subjetivismos e discricionaridades e, principalmente, considerando a necessidade do respeito ao autorregramento da vontade das partes, entende-se necessário elencar alguns fatores a serem analisados pelo juiz ao decidir pela invalidade ou não da convenção processual firmada por vulnerável.

Inicialmente, imperioso ressaltar que não há que se falar em invalidade do negócio caso não haja prejuízo ao vulnerável ${ }^{105}$. Tal entendimento deriva da regra geral "pas de nullité sans grief" e fundamentou a edição do Enunciado 16 do Fórum Permanente de Processualistas Civis, que possui a seguinte redação: “o controle dos requisitos objetivos e subjetivos de validade da convenção de procedimento deve ser conjugado com a regra segundo a qual não há invalidade do ato sem prejuízo.”. Isso já confirma, portanto, que nem sempre que toda convenção processual firmada por vulnerável será invalidada.

Ademais, entende-se que deve ser aferida a vulnerabilidade no caso concreto, bem como, verificada se esta, de fato, prejudicou a formação da convenção. Imagine-se a seguinte

\footnotetext{
${ }^{103}$ Nesse sentido: "A questão é buscar um equilíbrio entre publicismo e privatismo para descobrir qual a margem de negociabilidade no limite de atuação legítima do autorregramento da vontade." CABRAL, Antonio do Passo. Convenções processuais. 2. ed. Salvador: JusPodivm, 2018. p. 379.

104 ABREU, 2016, p. 298.

105 ATAÍDE JUNIOR, 2016, p. 273.
} 
situação: um profissional liberal, sem formação em Direito, firma contratos diariamente, sem a presença de advogado, e nesses contratos há uma cláusula de tentativa de autocomposição prévia. Suponha-se, ainda, que o profissional já fez uso dessa cláusula, em seu benefício, diversas vezes. Pode-se dizer que tal convenção será inválida tão somente em razão da ausência de advogado? Ainda, pode-se afirmar que o profissional é vulnerável técnico ou informacional?

Nesse sentido, o enunciado 18 do Fórum Permanente de Processualistas Civis possui a seguinte redação: "há indício de vulnerabilidade quando a parte celebra acordo de procedimento sem assistência técnico-jurídica". Veja-se que o enunciado fala em indício de vulnerabilidade, enquanto o parágrafo único do artigo 190 fala em "manifesta" vulnerabilidade. Deve-se, portanto, ter atenção às condições pessoais do convenente.

No exemplo mencionado, não há que se falar em vulnerabilidade do convenente para fins de controle de validade da convenção processual. De fato, é possível que o profissional seja um vulnerável processual. No entanto, tal fato não interfere na formação válida da convenção, posto que o indivíduo possuía condições de compreender os termos do negócio processual $^{106}$. Assim, conclui-se que o litigante, mesmo que considerado vulnerável processual, poderá firmar validamente convenções processuais, desde que se constate que sua vulnerabilidade não prejudicou sua compreensão sobre os termos do negócio.

Por fim, o juiz não poderá controlar, de ofício, a validade da convenção firmada pelo vulnerável. Isso porque não se pode considerar o vulnerável como um incapaz e invalidar uma convenção por ele firmada, sem seu requerimento, sob pena, inclusive, de violar seu direito ao autorregramento da vontade. Até mesmo porque, ainda que seja vulnerável, o convenente pode desejar a aplicação do negócio processual. Portanto, o Estado não pode presumir a vontade do litigante e, em seu lugar, entender pela ocorrência de prejuízo e decidir pela invalidação da convenção ${ }^{107}$.

Ante o exposto, ao controlar a validade da convenção processual, o juiz deve se ater a três critérios: i) a existência de prejuízo ao vulnerável; ii) aferição da vulnerabilidade no caso concreto, considerando se o convenente possuía condições de compreender os termos do negócio, e; iii) existência de requerimento da parte. Caso tais critérios não se evidenciem no

${ }^{106}$ CABRAL, 2018. p. 372.

${ }^{107}$ LUCCA, 2020, p. 42-43. 
caso concreto, o juiz não poderá recusar aplicação à convenção processual ${ }^{108}$.

O rigor ao analisar a necessidade de invalidação da convenção se justifica, pois, ao afastar sua aplicação, o magistrado estará mitigando o autorregramento da vontade das partes, o qual, conforme já mencionado durante o presente trabalho, também é um direito fundamental do litigante.

\section{CONCLUSÃO}

Pelo que consta no presente trabalho, foi possível perceber a incidência do princípio do autorregramento da vontade no Direito Processual Civil, consolidado, de forma definitiva, pelo Código de Processo Civil de 2015. Nesse sentido, vimos a ampla possibilidade de negociação processual possibilitada pelo artigo 190 da referida lei, a qual é considerada uma cláusula geral de negociação processual, que permite que os litigantes convencionem sobre o procedimento, sobre seus ônus, poderes, faculdade e deveres.

No entanto, o parágrafo único do referido dispositivo impõe limites ao autorregramento da vontade, ao prever que o juiz controlará a validade das convenções quando houver nulidade, inserção abusiva em contrato de adesão ou manifesta vulnerabilidade da parte.

Quanto a esta última hipótese, analisamos a vulnerabilidade em âmbito processual, a partir de premissas relacionadas à igualdade, também aplicada ao processo, em especial no que concerne à igualdade como pressuposto da liberdade do litigante.

Por fim, como objetivo do presente estudo, buscamos elencar os critérios que devem ser analisados pelo juiz ao controlar a validade da convenção processual firmada por vulnerável, levando em conta, principalmente, que direito ao autorregramento da vontade das partes somente pode ser mitigado em hipóteses excepcionais, posto ser, ao lado da igualdade, um direito fundamental.

\section{REFERÊNCIAS}

${ }^{108}$ DIDIER JR., Fredie. Negócios jurídicos processuais atípicos no CPC-2015. p. 41. In: DIDIER JR., Fredie. Ensaios sobre os negócios jurídicos processuais. Salvador: Editora JusPodivm, 2018. p. 25-46. 
ABREU, Rafael Sirangelo. A Igualdade e os Negócios Processuais. In: CABRAL, Antonio do Passo; NOGUEIRA, Pedro Henrique (Coord.). Negócios processuais. Tomo 1. 2 ed. Salvador: JusPodivm, 2016.

ATAÍDE JUNIOR, Jaldemiro Rodrigues. Negócio jurídicos materiais e processuais existência, validade e eficácia - campo-invariáriel e campos-dependentes: sobre os limites dos negócios jurídicos processuais. In: CABRAL, Antonio do Passo; NOGUEIRA, Pedro Henrique (Coord.). Negócios processuais. Tomo 1. 2 ed. Salvador: JusPodivm, 2016.

BARBOSA, Rafael Vinheiro Monteiro; MAIA, Maurílio Casas. Isonomia dinâmica e vulnerabilidade no direito processual civil. Revista de Processo. vol. 230/2014. p. 349365.

BEDAQUE, José Roberto dos Santos. Direito e processo: a influência do direito material sobre o processo. 2. ed. São Paulo: Malheiros, 2001.

BOBBIO, Norberto. Igualdade e liberdade. Tradução de Carlos Nelson Coutinho. 2. ed. Rio de Janeiro: Ediouro, 1997.

BRASIL. Constituição (1988). Constituição da República Federativa do Brasil. Brasília: Senado, 1988. . Lei 10.406/2002. Código Civil. Brasília: Congresso Nacional, 2002. . Lei 13.105/2015. Código de Processo Civil (2015). Brasília: Congresso Nacional, 2015.

Lei 5.869/1973. Código de Processo Civil (1973). Brasília: Congresso Nacional, 1973.

CABRAL, Antonio do Passo. Convenções processuais. 2. ed. Salvador: JusPodivm, 2018.

CABRAL, Antonio do Passo; NOGUEIRA, Pedro Henrique (Coord.). Negócios processuais. Tomo 1. 2 ed. Salvador: JusPodivm, 2016. . Negócios processuais. Tomo 2. Salvador: JusPodivm, 2020.

CAMBI, Eduardo. Neoconstitucionalismo e neoprocessualismo: direitos fundamentais, políticas públicas e protagonismo judiciário. 2. ed. São Paulo: Revista dos Tribunais, 2011.

CAPPELLETTI, Mauro; GARTH, Bryant. Acesso à justiça. Porto Alegre: Fabris, 1988.

CINTRA, Antonio Carlos de Araújo; GRINOVER, Ada Pellegrini; DINAMARCO, Cândido 
Rangel. Teoria geral do processo. 29. ed., rev. e atual. São Paulo: Malheiros, 2013.

CUNHA, Leonardo Carneiro. Negócios Jurídicos Processuais no Processo Civil Brasileiro. In: CABRAL, Antonio do Passo; NOGUEIRA, Pedro Henrique (Coord.). Negócios processuais. Tomo 1. 2 ed. Salvador: JusPodivm, 2016.

DIDIER JR., Fredie. Curso de Direito Processual Civil, vol. I, 12 ed., Salvador: JusPodivm, 2010 .

. Ensaios sobre os negócios jurídicos processuais. Salvador: Editora JusPodivm, 2018 .

DINAMARCO, Cândido Rangel. A instrumentalidade do processo. 14. ed., rev. e atual. São Paulo: Malheiros, 2009.

FÓRUM PERMANENTE DE PROCESSUALISTAS CIVIS. Carta de Florianópolis. 2017. GODINHO, Robson Renault. A possibilidade de negócios jurídicos processuais atípicos em matéria probatória. In: CABRAL, Antonio do Passo; NOGUEIRA, Pedro Henrique (Coord.). Negócios processuais. Tomo 1. 2 ed. Salvador: JusPodivm, 2016.

HESSE, Konrad. Derecho constitucional y derecho privado. Madrid: Civitas, 2001.

KELSEN, Hans. Teoria pura do direito. 6. ed. São Paulo: Martins Fontes, 1998.

KONDER, Carlos Nelson. Vulnerabilidade patrimonial e vulnerabilidade existencial: por um sistema diferenciador. Revista de Direito do Consumidor. vol. 99/2015. p.101-123.

LUCCA, Rodrigo Ramina de. Liberdade, autonomia e convenções processuais. In: CABRAL, Antonio do Passo; NOGUEIRA, Pedro Henrique (Coord.). Negócios processuais. Tomo 2. Salvador: JusPodivm, 2020.

MARINONI, Luiz Guilherme. Novas linhas do processo civil. 4. ed. São Paulo: Malheiros, 2000.

MIRANDA, Pontes de. Democracia, liberdade, igualdade: os três caminhos. 1. ed. Campinas: Bookseller, 2002.

MITIDIERO, Daniel. Colaboração no Processo Civil: pressupostos sociais, lógicos e éticos.

2. ed. São Paulo: Revista dos Tribunais, 2011.

MOREIRA, José Carlos Barbosa. A função social do processo civil moderno e o papel do juiz e das partes na direção e na instrução do processo. Revista de processo. vol. 37/1985. p. 140-150.

NOGUEIRA, Pedro Henrique. Sobre os Acordos de Procedimento no Processo Civil 
Brasileiro. In: CABRAL, Antonio do Passo; NOGUEIRA, Pedro Henrique (Coord.).

Negócios processuais. Tomo 1. 2 ed. Salvador: JusPodivm, 2016.

OLIVEIRA, Carlos Alberto Alvaro de; MITIDIERO, Daniel. Curso de Processo Civil. vol.

I. São Paulo: Atlas, 2010.

PRATA, Ana. A tutela constitucional da autonomia privada. Coimbra: Livraria Almedina, 1982.

REDONDO, Bruno Garcia. Negócios processuais: necessidade de rompimento radical com o sistema do CPC/1973 para a adequada compreensão da inovação do CPC/2015. In: CABRAL, Antonio do Passo; NOGUEIRA, Pedro Henrique (Coord.). Negócios processuais. Tomo 1. 2 ed. Salvador: JusPodivm, 2016.

RIBEIRO, Darci Guimarães. O papel do processo na construção da democracia: para uma nova definição de democracia participativa. In: Da tutela jurisdicional às formas de tutela. Porto Alegre: Livraria do Advogado, 2010.

SARMENTO, Daniel. Direitos fundamentais e relações privadas. 2. ed. Rio de Janeiro: Lumen Juris, 2006.

SOARES, Lara Rafaelle Pinho. A Vulnerabilidade na Negociação Processual Atípica. 2016, 185 f. Dissertação (Mestrado em Direito Público). - Universidade Federal da Bahia, Salvador, 2016.

TARTUCE, Fernanda. Igualdade e vulnerabilidade no processo civil. Rio de Janeiro: Forense, 2012.

TUCCI, José Rogério Cruz e. Natureza e objeto das convenções processuais. In: CABRAL, Antonio do Passo; NOGUEIRA, Pedro Henrique (Coord.). Negócios processuais. Tomo 1. 2 ed. Salvador: JusPodivm, 2016. 